\title{
BITUMEN COMPOSITION OF IMPROVED QUALITY FOR PAVING
}

\author{
D.S.MammadHasan-zade, I.Kh.Ibragimov \\ Azerbaijan State Oil and Industry University \\ dilara.memmed1955@gmail.com
}

Received 23.10.2019

Accepted 15.01.2020

\begin{abstract}
The article presents the results of secondary polyethylene modification of oil asphalt containing 2.0$2.8 \%$ of rubber crumbs. It is shown that at an optimal concentration of black oil M-40 in the content of bitumen composition with an increase in the amount of the introduced plasticizer - secondary polyethylene - from 1.4 to 4.0 mass $\%$, the softening point of the final product varies from 46 to $80^{\circ} \mathrm{C}$, and the extensibility index - from 4 to $13 \mathrm{~cm}$.
\end{abstract}

Keywords: secondary polyethylene, black oil, rubber crumbs, softening point, extensibility.

doi

\section{Introduction}

Creation of a solid and durable basis for paving, the quality of which is determined by the physical-mechanical properties of the used binder, is of current importance throughout the world. Road bitumen used to produce paving for quality does not always meet the demands, and therefore much attention is paid to the research on the modification of the operational qualities of bitumen by introducing various additives into the content of bituminous compositions, including waste from various industries, as well as polymeric materials waste.

In recent years, bitumen compositions modified with various polymeric waste, in particular polyisoprene rubbers (SKI - 3), divinylstyrene thermoplastic elastomer, ethylene-propylene copolymers, waste from thermoplastic polymers and production of high pressure polyethylene etc., have been widely used to create a practical paving [1-5].

In the present paper, spited are the results of the research describe the impact of black oil M-40 concentration, as well as the secondary polyethylene, which is involved as a plasticizer in the bitumen composition for paving.

\section{Experimental part}

In the investigations being conducted, in accordance with GOST black oil M-40 10585-99 characterized by kinematic viscosity at $80^{\circ} \mathrm{C}$ equal to $43 \mathrm{~mm}^{2} / \mathrm{s}$, density at $20^{\circ} \mathrm{C}-922.1 \mathrm{~kg} / \mathrm{m}^{3}$, freezing point is minus $12^{\circ} \mathrm{C}$, flash point $-184^{\circ} \mathrm{C}$, ash content -0.0228 mass $\%$ is used. The mass fraction of sulfur was $0.23 \%$.

As a raw material, bitumen, characterized by a softening point in $\mathrm{KS}-110^{\circ} \mathrm{C}$, penetration depth of the needle at $25^{\circ} \mathrm{C}-16 \times 0.1 \mathrm{~mm}$ and extensibility at $25^{\circ} \mathrm{C}-3 \mathrm{~cm}$ is used.

As a rubber crumb, industrial rubber products waste with a diameter of $0.06 \mathrm{~mm}$ was used.

Stirring obtained mixture was heated to $160-170^{\circ} \mathrm{C}$ in order to provide complete dissolution of rubber crumbs in fluidizing bitumen. The bitumen composition obtained at this temperature sustained for the additional 30-40 min to ensure homogeneity, then the indices were determined.

\section{Results and discussion}

Technical characteristics of the obtained bitumen compositions are given in Table 1 .

As is seen from Table 1, an increase in the proportion of black oil M-40 added to the content of bituminous compositions to 26-28 mass $\%$ ensures complete swelling of rubber crumbs and contributes to reduce the softening point of the high-melting bitumen taken as raw materials from $110^{\circ} \mathrm{C}$ to $51-62^{\circ} \mathrm{C}$, softening point of oil road asphalt of BND 60-90 in accordance with GOST 1150673. In addition, the obtained samples of bitumen composition are characterized by relatively high penetration and extensibility parameters at $25^{\circ} \mathrm{C}$. In particular, the depth of penetration of the needle was shown to increase from $16 \times 0.1 \mathrm{~mm}$ to $84-95 \times 0.1 \mathrm{~mm}$, and the extensibility from 3 to $4-7 \mathrm{~cm}$. 
The specified concentration of black oil makes it possible to obtain a homogeneous composition by introducing it into the content 2-2.8 mass $\%$ of rubber crumbs that increases the service life of paving.

The investigation cycle on modification of astringent bitumen for paving was carried out using secondary polyethylene as a plasticizer.

The composition content involving secondary bitumen is also carried out by the above mentioned technique: heating a mixture of bituminous raw materials and black oil to 60$70^{\circ} \mathrm{C}$ obtained at the above mentioned concentration of the latter was continuously mixed by adding a certain amount of the mentioned polymer and the mixture was heated to $120^{\circ} \mathrm{C}$, then to $160-170^{\circ} \mathrm{C}$. The obtained composition was held at this temperature for 30-40 minutes and then the physical-mechanical properties were determined.

The obtained results presented in Table 2 testify to the plasticizing effect of the secondary polyethylene added into the content of the bituminous composition. In this case, according to softening point on KS of the bitumen compositions obtained with the introduction of 1.4-4 mass $\%$ of secondary polyethylene, decreases from $110^{\circ} \mathrm{C}$ to $46-80^{\circ} \mathrm{C}$.

Table 1. Physical-mechanical properties of bituminous compositions

\begin{tabular}{|c|c|c|c|}
\hline Name & $\begin{array}{c}\text { Softening point according } \\
\text { to KS, }{ }^{0} \mathrm{C} \\
\text { GOST } 11506-73\end{array}$ & $\begin{array}{c}\text { Penetration depth of the } \\
\text { needle at } 25^{\circ} \mathrm{C} \times 0.1 \mathrm{~mm} \\
\text { GOST } 11501-73\end{array}$ & $\begin{array}{c}\text { Extensibility, sm at } 25^{\circ} \mathrm{C} \\
\text { GOST } 11505-75\end{array}$ \\
\hline $\begin{array}{l}\text { GOST } 22245-90 \text { on bitumen } \\
\text { oil road BND } 60 / 90 \text { grade }\end{array}$ & f.s. 47 & $61-90$ & 55 \\
\hline bitumen (raw material) & 110 & 16 & 3 \\
\hline $\begin{array}{l}\text { bituminous composition: } \\
\text { bitumen-72.0 mass } \% \\
\text { rubber crumb-2.0 mass } \% \\
\text { black oil-26.0 mass } \%\end{array}$ & 51 & 95 & 4 \\
\hline $\begin{array}{l}\text { bituminous composition: } \\
\text { bitumen-70.1 mass } \% \\
\text { rubber crumb-2.5 mass } \% \\
\text { black oil-27.4 mass } \%\end{array}$ & 62 & 84 & 5 \\
\hline $\begin{array}{l}\text { bituminous composition: } \\
\text { bitumen-69.2 mass } \% \\
\text { rubber crumb-2.8 mass } \% \\
\text { black oil-28.0 mass } \%\end{array}$ & 54 & 90 & 7 \\
\hline
\end{tabular}

*factory standard

Table 2. Physical-mechanical properties of the obtained bituminous compositions

\begin{tabular}{|c|c|c|c|c|}
\hline $\mathrm{N}$ & Name & $\begin{array}{l}\text { Softening point } \\
\text { according to KS, }{ }^{0} \mathrm{C} \\
\text { GOST } 1506-73\end{array}$ & $\begin{array}{l}\text { Penetration depth of the } \\
\text { needle at } 25^{\circ} \mathrm{C} \times 0.1 \mathrm{~mm} \\
\text { GOST } 11501-73\end{array}$ & $\begin{array}{l}\text { Extensibility, sm. } \\
\text { at } 25^{\circ} \mathrm{C} \\
\text { GOST } 11505-75\end{array}$ \\
\hline & Bitumen (raw material) & 110 & 16 & 3 \\
\hline I & $\begin{array}{l}\text { Experiment } 1 . \text { Bituminous composition: } \\
\text { Bitumen }-70.6 \text { mass } \% \\
\text { Secondery polyethylene }-1.4 \text { mass } \% \\
\text { Black oil }-28.0 \text { mass } \%\end{array}$ & 46 & 71 & 13 \\
\hline II & $\begin{array}{l}\text { Experiment } 2 . \text { Bituminous composition: } \\
\text { Bitumen- } 69.4 \text { mass } \% \\
\text { Secondery polyethylene }-4.0 \text { mass } \% \\
\text { Black oil }-27.8 \text { mass } \%\end{array}$ & 63 & 80 & 6 \\
\hline III & $\begin{array}{l}\text { Experiment } 3 \text {. Bituminous composition: } \\
\text { Bitumen }-69.0 \text { mass } \% \\
\text { Secondery polyethylene }-4.0 \text { mass } \% \\
\text { Black oil }-27.0 \text { mass } \%\end{array}$ & 80 & 51 & 4 \\
\hline
\end{tabular}


With this, the compositions obtained with a content 1.4 mass $\%$ of secondary polyethylene are characterized by relatively low softening point index, that obviously related to obtaining a homogeneous composition content. This, the resulting sample of bitumen composition is characterized by a better extensibility index at $25^{\circ} \mathrm{C}$ $(13 \mathrm{~cm})$, against $3 \mathrm{~cm}$ for the initial material.

With the increase in the amount of secondary polyethylene introduced into the bitumen content, the obtained composition is characterized by relatively high melting point $\left(80^{\circ} \mathrm{C}\right)$, as well as an extensibility $(4 \mathrm{~cm})$, that may be related to both - with seal of the obtained bitumen composition and heterogeneity.

Thus, the conducted research cycle found that the bitumen composition obtained by modifying the introduction of additive as plasticizing secondary polyethylene in the amount of $1.4-$ 4.0 and $27-28$ mass $\%$ of the fluidizing compo- nent of black oil possess improved parameters, and thereby allows the use of the mentioned composition under various climatic conditions.

\section{References}

1. Leonenko V.V., Safarov G.A. Nekotorye aspekty, modifikatcii bitumov polimernymi materialami. Himiia i tekhnologiia topliv i masel. 2001. № 5. S. 43-49.

2. Nehoroshev V.P., Rossel L.P. Modifitcirovanie svoistv dorozhnykh bitumov plastifikatorami na osnove takticheskogo polipropilena. Neft i gaz Zapadnoi Sibiri: Sb.statei vseross. nauchno-tekhnich. konf. Tiumen: Izd-vo Tiumgu, 2005. C. 268-269.

3. Rozental D.L., Tobolina M.S., Fedosova V.A. Modifikatciia bitumov polimernymi dobavkami. Pererabotka nefti. Tematicheskii obzor. 1988. Vyp. 6. S. 15. 42.

4. Schulte Wolfqand. Temperatura bsenkungim Asphaltstrabenbau. Asphalt (BRD). 2003. № 2. S. 38.

5. Muhamatdinov I.I., Galimullin I.N. Adgezionnye prisadki dlia bitumov dorozhnogo pokrytiia. Neftepererabotka i neftehimiia. 2017. № 2. S. 33-37.

\section{XASSЭLӘRİ YAXŞILAŞDIRILMIŞ YOL ÖRTÜYÜ BİTUM KOMPOZISIYYASI}

\section{D.S.MəmmədHəsən-zadə, İ.H.İbrahimov}

Məqalədə tərkibində 2.0-2.8\% kütlə rezin qırıntıları saxlayan neft bitumunun təkrar emal polietilenlə modifikasiyasının nəticələri verilmişdir. Göstərilmişdir ki, tərkibində 26-28\% M-40 markalı mazut saxlayan bitum kompozisiyasına modofikator kimi daxil edilən təkrar emal polietilenin miqdarı 1.4-4.0\% kütlə artdıqca son məhsulun Halqa və Şar (H və Ş) üsulu ilə yumşalma temperaturu $46-80^{\circ} \mathrm{C}$, dartılma göstərici isə $4-13 \mathrm{sm}$ intervalında dəyişir.

Açar sözlari: yol bitumu, modifikasiya, plastifikator, təkrar emal polietilen, bağlayıcı.

\section{БИТУМНЫЙ СОСТАВ УЛУЧШЕННОГО КАЧЕСТВА ДЛЯ ДОРОЖНОГО ПОКРЫТИЯ}

\section{Д.С.Мамед-Гасанзаде, И.Х.Ибрагимов}

Представлены результаты модификации вторичными полиэтиленом нефтяного битума, содержащего 2.0-2.8\% резиновой крошки. Показано, что при оптимальной концентрации мазута марки М-40 в содержании битумной композиции при увеличении количества вводимого пластификатора - вторичного полиэтилена с 1.4 до 4.0 масс \% точка размягчения конечного продукта изменяется от 46 до $800^{\circ} \mathrm{C}$, а индекс растяжимости - от 4 до 13 см.

Ключевые слова: вторичный полиэтилен, мазут, резиновая крошка, точка размягчения, растяжимость. 